\title{
PEDAGOGICAL UNIVERSITY STUDENTS' PERCEPTION OF THE COURSE ON INTRODUCTION TO GERMANIC LINGUISTICS
}

\author{
Galyna Palytsya \\ Drohobych Ivan Franko State Pedagogical University, Drohobych, Ukraine \\ gpalytsya73@gmail.com \\ Oksana Storonska \\ Drohobych Ivan Franko State Pedagogical University, Drohobych, Ukraine \\ okstoronska@gmail.com
}

\begin{abstract}
The present article investigates foreign language teacher training quality enhancement by surveying pedagogical university students' opinions on important aspects of the course of Introduction to Germanic Linguistics within the Educational Programme for Bachelor's Degree in Education. The prime purpose is to study the perception of the above-mentioned optional course by Drohobych Ivan Franko State Pedagogical University (DIFSPU) students, with a focus on its content, organization and relevance to foreign language teacher training as well as on its professional competence formation efficiency. The complexity of the problems involved requires a combination of different methods, i.e. empirical, theoretical and statistical ones. 42 undergraduate DIFSPU students majoring in 014 "Secondary Education (English Language and Literature)" and 014 "Secondary Education (German Language and Literature)" took part in the experiment. The main survey tool was a questionnaire reflecting the parameters of assessing the course of Introduction to Germanic Linguistics. The data collected provides a solid basis for the revision of the course content, structure, organization, educational significance and efficiency, based on the direct participants' assessments and comments. The students' feedback reveals: 1) unanimous approval of the content and organizational principles of the discipline; 2) mixed opinions on its importance in the structure of the Educational Programme for Bachelor's Degree in Education; 3) variability of the course efficiency assessments. The data obtained allow for determining the conditions of an efficient implementation of Introduction to Germanic Linguistics into educational practice, such as prior familiarization of students with its aim and essence, emphasis on its applicability and optionality as well as its adaptation to the level and needs of future teachers. The data interpretation equally contributes to establishing the prospects of enhancing the course: 1) proportionalizing diverse types of educational activities; 2) increasing flexibility and variability in the educative process organization; 3) more efficiently interiorizing its content in terms of professional education priorities for future teachers of the English and German languages.
\end{abstract}

Keywords: pedagogical university students; foreign language teachers; philological training; Introduction to Germanic Linguistics; perception.

\section{Introduction}

Philological training is the core component of foreign language teacher education, which has a dual function. On the one hand, it is aimed at transmitting knowledge about language as an attribute of human existence with a variety of functions and roles; as a heterogeneous systemic phenomenon with many elements and units; as a unique means of communication with numerous realization options. On the other hand, it presents a foreign language with its adequate pronunciation, vocabulary richness, plurality of grammatical structures and variability of lects. Philological training equally approaches the foreign language with respect to its origin, formation and further evolution trends along with revealing its social nature both on a national scale and globally. Thus, this linguistic training focus provides future foreign language teachers with a holistic vision of the essence of the subject taught in its diversity, versatility, multifunctionality, internal relationships and external interactions.

The importance of the problem of thorough philological training of language teachers has made it a key research priority of the academic community both on a national and global scale. The topics it aims to investigate reflect a wide variety of issues, such as the nature and functions of linguistic training in the system of professional education of foreign language teachers alongside the elaboration of effective approaches to its implementation with increased emphasis on the specifics of their professional area (Correa, 2014); the role and significance of linguistic disciplines in the development of professional competence of foreign language teachers (Mendelsohn, 2011); the influence of professional philological disciplines on the improvement of foreign language teachers' linguistic competence (Bosa, 2019); the effectiveness of linguistic courses in the formation of systemic linguistic knowledge, skills and abilities of foreign language teachers (Fenwick et al., 2014); the content, structure and forms of professional philological training

(C Galyna Palytsya, Oksana Storonska. 2021. Published by Igor Sikorsky Kyiv Polytechnic Institute. This is an Open Access article distributed under the terms of the licence CC BY 4.0 
(Lipinska, 2013; Volotivska, 2017); modern interactive technologies of linguistic training of foreign language teachers (Melnychenko, 2016), etc.

Extensive research into the issues of philological training of foreign language teachers is marked by a clear focus on its structural, organizational, conceptual, methodological, etc., aspects primarily in the light of its current objectives. All these works prioritise the problem of formation of pedagogical university students' linguistic competence, metalinguistic knowledge or philological worldview providing a basis for their successful professional self-fulfilment, especially in the context of the complexity and non-standard nature of their professional responsibilities and tasks, rapid advances in the professional sphere, steady progress in linguistics and related disciplines, etc. (Andrews and McNeill, 2005; Başyurt Tüzel and Akcan, 2009; Bezliudna, 2017; Otwinowska, 2017). Furthermore, they focus on a constant reassessment and re-evaluation of the structure, content, methods, techniques, etc. of philological training in order to promote the formation of the professional qualities above as well as on a continuous further search for ways and means to ensure its quality and efficiency (Bigelow and Ranney, 2010; Ellis, 2012; Arias-Cepeda and Rojas, 2017).

In this context, it proves quite appropriate and rational for researchers to appeal directly to foreign language teachers for their opinion on the quality of philological training and opportunities for its improvement. A seminal work in this research area is a study by Banegas (2020), highlighting the evaluative attitude of foreign language teachers to the process and results of their linguistic training in Argentine's higher education institutions. Its key provisions reveal the significance of linguistic training of foreign language teachers; the essence of their linguistic competence as the net result to be obtained; the methods and means of its formation in the process of learning diverse branches of linguistics. It is on this theoretical basis that the author not only conducted a study of future foreign language teachers' evaluative judgements on the course called Introduction to Linguistics but also summarised their reflections on the linguistic competence they had achieved. Finally, as a result of a thorough analysis and systemization of all the collected data, Banegas suggested constructive ideas to improve the course quality.

Another notable study in this field is that by Hatipoğlu (2017), dealing with the peculiarities of future foreign language teachers' opinion on their linguistic training at Middle East Technical University in Ankara. We consider valuable the author's thorough analysis of the role, place and proportion of linguistic disciplines in the relevant syllabus, her comprehensive description of their content and implementation forms in the educative process, her objective examination of the students' evaluative judgments concerning the importance and efficiency of linguistic disciplines in the formation of their professional competences, etc. As a result, the research provides a solid basis for establishing the full range of foreign language teachers' evaluative opinions on the quality of their linguistic training, establishing appropriate cause-and-effect links, and substantiating a number of useful recommendations and guidelines.

Abreu's research (2015) is also noteworthy in that it is aimed at identifying and analysing foreign language teachers' beliefs about the relevance and effectiveness of an optional course in Applied Linguistics within the structure of their syllabus for Master's Degree at the University of Southern Mississippi. The author substantiates the role and importance of linguistic disciplines in foreign language teacher training, highlights the specifics of Applied Linguistics as a course and presents the survey findings on its efficiency in developing professional competences. The research offers a detailed analysis of the dynamics of foreign language teachers' evaluative judgements changing progressively in the course of their studies. Furthermore, Abreu provides theoretically and practically significant conclusions and suggestions expected to enhance the course quality.

Therefore, global research practice prioritises the importance and efficiency of appealing to future foreign language teachers for their feedback on various components of their linguistic training. It is this academic stance that has inspired our attempt at adapting this approach to investigating the propaedeutic course of Germanic linguistics intended for future teachers of the English and/or German languages at DIFSPU, since the discipline has not been approached academically from this perspective yet. The course correlates with the general aims of the Educational Programme for Bachelor's Degree in Education, namely the Specialties 014 "Secondary Education (English Language and Literature)", 014 "Secondary Education (German Language and Literature)", with a particular focus on the aim to "[... ] train the teaching staff possessing a profound fundamental theoretical and practical knowledge of linguistics [...]" (Kemin et al., 2019a, p.3; 2019b, p.3). It occupies an intermediate position in the structural and logical layout of the educational programmes above, i.e. between the general philological discipline Introduction to Linguistics, on the one hand, and the special linguistic courses of History of the English (German) Language, Theoretical Phonetics of the English (German) Language, Theoretical Grammar of the English (German) Language and Lexicology of the English (German) Language, on the other. 
Introduction to Germanic Linguistics is conceptualised as a tool of expanding and deepening basic linguistic training of pedagogical university students with English (German) as their first major within the educational programmes specified above. Therefore, it is an optional discipline suggested for study in the third term and equivalent to 6 ECTS credits. Its aim is to broaden future English/German language teachers' knowledge about the origin and development of the Germanic language group, its interactions within the Indo-European language family and the acquisition of skills in comparative-historical analysis of such areas of the Old Germanic languages as phonetics, vocabulary and grammar. The choice of these aims determines the content of the course, which reflects a number of topics: the formation of Germanic linguistics as a discipline; the Indo-European language community and the place of the Germanic languages in it; the old Germanic tribes and ethnic groups along with their social structure and culture; the phonetic system of the Old Germanic languages; the grammatical structure of the Old Germanic languages; the Old Germanic vocabulary; the Modern Germanic languages, etc. The syllabus of the discipline includes lectures (30 academic hours), tutorials (30 academic hours), self-study (120 academic hours), and assessment in the form of oral and written tests, colloquium and examination.

The aim of our article is to study DIFSPU students' perception of the discipline Introduction to Germanic Linguistics (Specialties 014 "Secondary Education (English Language and Literature)", 014 "Secondary Education (German Language and Literature)"). The objectives of the present article are to collect, systemise and interpret the students' evaluation of the content and organization of the discipline as well as to obtain their opinions regarding the relevance of the course in the structure of their educational programmes and its effectiveness in the formation of professional competences. Our hypothesis is that the data collected in accordance with the aim and objectives will contribute to clarifying the specifics of the propaedeutic course of Germanic linguistics as a component of professional and philological training of teachers of English/German along with outlining the ways of improving it so as to meet the students' expectations.

\section{Methods}

Research Design

The problems identified in our article rely on methodological pluralism, which involves combining a set of research methods to achieve the aims and objectives above. Empirical methods (questionnairing) are used to collect factual material and form the research basis. Statistical methods are utilised to calculate, systemise and present the quantitative data obtained. Theoretical general scientific methods including analysis, synthesis, classification, interpretation and generalization are employed to thoroughly process all the collected information, formulate the main provisions of the study and summarise the research results.

\section{Participants}

The survey covers 42 DIFSPU students majoring in the Specialties 014 "Secondary Education (English Language and Literature)" and 014 "Secondary Education (German Language and Literature)". By the time the survey was conducted, all the participants had successfully completed the course Introduction to Germanic Linguistics in the first term of the 2020/2021 academic year. As a result of the survey, 40 fully completed questionnaires were obtained, which constitutes our empirical research basis.

\section{Instruments and Procedur}

The main data collection tool is a questionnaire as a structurally organised set of questions logically correlating with the main aims and objectives of our study. The questionnaire contains three parts. The first two parts include five closed-ended questions each and reflect the key assessment parameters of Introduction to Germanic Linguistics as a discipline, including its content, organization and relevance to the Educational Programme of professional training of teachers of English and German as foreign languages. The first part is aimed at assessing the information content quality, the rationale behind the thematic structure, the course load balance, the organization efficiency as well as the relevance of the teaching tools. The second part is aimed at assessing the professional and scientific information content of the discipline, its compliance with the requirements to the educational specialities in question, its consistency in the scheme of other university disciplines as well as its status rationality. These aspects of the course are assessed with the help of a fivepoint Likert scale (from 1 - "very low" to 5 - "very high"). The third part of the questionnaire concerns the efficiency of Introduction to Germanic Linguistics and features two open-ended questions requiring the participants to comment on their own learning achievements and to give their feedback upon fully completing the course ("Was Introduction to Germanic Linguistics efficient in improving your professional competence?" and "What professional knowledge, skills and abilities have you acquired as a result of studying Introduction to Germanic Linguistics?"). Each section is also designed so as to provide an opportunity to comment on one's responses and express one's suggestions. The experiment procedure 
involved three phases: 1) informing the participants in detail about its aims and applicability of the results; 2) thoroughly explaining the questionnaire items as well as providing instructions for their correct completion; 3) the questionnaire completion by the respondents.

\section{Data Analysis}

The processing of the information collected in the survey included two stages: 1) the statistical calculation and systemization of the quantitative data in the Excel spreadsheet format, accompanied by the identification and indication of frequencies and percentages; 2) the analysis, interpretation and generalization of the qualitative data obtained. Such data analysis sequence allows for the objective yet time-efficient processing of the participants' answers.

\section{Ethical Issues}

The experimental study was conducted with respect for human rights and ethical principles. All the participants were informed in advance of their right to participate or not. The survey was declared completely anonymous, so the questionnaire did not contain any items that would identify the participants (surname, age, group, etc.).

\section{Results}

The research methodology above allows us to identify a wide range of the respondents' evaluative judgements and opinions concerning the three key parameters of the course of Introduction to Germanic Linguistics. The first parameter is the content and organization of the discipline, which involves assessing its information relevance, structure consistency, course load balance, organization constructiveness and teaching tools efficiency. The results obtained prove that the overwhelming majority of the respondents were unanimous in approving the information relevance of the course (95\%), its teaching materials efficiency $(90 \%)$, structure consistency $(87.5 \%)$, organization constructiveness $(82.5 \%)$ and load balance $(67.5 \%)$. Against this background, the insignificant number of low and very low ratings of these aspects of Introduction to Germanic Linguistics is natural and constitutes from 0\% to 5\% depending on the criterion. The students' comments include their suggestions for simplifying the course organization in distance learning conditions as well as increasing the share of classroom work, especially through tutorials. The full range of the students' feedback is provided in a detailed and systemised form in Table 1 below.

Table 1. The content and organization of the course of Introduction to Germanic Linguistics (according to the students' feedback)

\begin{tabular}{|lccccc|}
\hline \multicolumn{1}{c}{ Variables } & \multicolumn{5}{c|}{ Rating scale } \\
\cline { 2 - 6 } & Very high & High & Average & Low & Very low \\
\hline 1. Information relevance & $72.5 \%$ & $22.5 \%$ & $2.5 \%$ & $2.5 \%$ & $0 \%$ \\
2. Structure consistency & $57.5 \%$ & $30 \%$ & $10 \%$ & $2.5 \%$ & $0 \%$ \\
3. Course load balance & $35 \%$ & $32.5 \%$ & $27.5 \%$ & $5 \%$ & $0 \%$ \\
4. Organization constructiveness & $47.5 \%$ & $35 \%$ & $15 \%$ & $2.5 \%$ & $0 \%$ \\
5. Teaching tools efficiency & $77.5 \%$ & $12.5 \%$ & $10 \%$ & $0 \%$ & $0 \%$ \\
\hline
\end{tabular}

The second parameter is the relevance of Introduction to Germanic Linguistics to the structure of the educational programme of professional training of teachers of English/German, which is meant to determine the course efficiency and usefulness from the respondents' perspective. Thus the course was assessed according to the following five criteria: connection with the realities of teaching languages, professional and scientific information content, compliance with the educational speciality, consistency in the system of disciplines and status rationality. The data obtained testify to the variability and sometimes even ambivalence of the students' evaluation of Introduction to Germanic Linguistics. On the one hand, the vast majority of the respondents state a high level of the professional and scientific information content of the course (87.5\%), its consistency in the system of academic disciplines (75\%), status rationality (70\%), connection with the realities of the profession of an English/German language teacher (60\%) and compliance with the educational speciality $(60 \%)$. On the other hand, we note significant discrepancies in their opinions as well as a higher frequency of the negative ratings of certain aspects of the course (ranging from $2.5 \%$ to $7.5 \%$ ) within each criterion. However, the students' comments include only sporadic suggestions for shifting the course focus to the linguistic processes and phenomena of primarily English/German. The wide range of the students' feedback is clearly and exhaustively shown in Table 2 below. 
Table 2. Relevance of the course "Introduction to Germanic Linguistics" to the structure of the educational programme of English/German teachers' professional training (according to the students' feedback)

\begin{tabular}{|lccccc|}
\hline \multicolumn{1}{c}{ Variables } & \multicolumn{4}{c|}{ Rating scale } \\
\cline { 2 - 6 } & Very high & High & Average & Low & $\begin{array}{c}\text { Very } \\
\text { low }\end{array}$ \\
\hline 1. Connection with the realities of the profession & $32.5 \%$ & $27.5 \%$ & $32.5 \%$ & $5 \%$ & $2.5 \%$ \\
2. Professional and scientific information content & $65 \%$ & $22.5 \%$ & $7.5 \%$ & $5 \%$ & $0 \%$ \\
3. Compliance with the educational speciality & $37.5 \%$ & $22.5 \%$ & $32.5 \%$ & $7.5 \%$ & $0 \%$ \\
4. Consistency in the system of disciplines & $55 \%$ & $20 \%$ & $22.5 \%$ & $2.5 \%$ & $0 \%$ \\
5. Status rationality & $37.5 \%$ & $32.5 \%$ & $22.5 \%$ & $7.5 \%$ & $0 \%$ \\
\hline
\end{tabular}

The third parameter is the efficiency of Introduction to Germanic Linguistics as a discipline, which is aimed at interpreting the opinions of future teachers of English/German concerning the direct impact of the course on their professional development and their own academic achievements while mastering it. According to the data obtained, $82.5 \%$ of the respondents noted the efficiency of Introduction to Germanic Linguistics in the formation of their professional competence. Conversely, 5\% pointed to its inefficiency in raising their professional level. The remaining $12.5 \%$ could not make up their mind and answer unambiguously. Therefore, the efficiency of Introduction to Germanic Linguistics, acknowledged by $82.5 \%$ of the respondents of our study, was supported by a number of their well-argued statements, which are presented in the following systemised and somewhat generalised formulations reflecting their learning outcomes:

1) mastering the methodology and terminology of Germanic linguistics (6.1\%);

2) approaching the Germanic languages as a unity within the Indo-European language family (24.2\%);

3 ) distinguishing the sociohistorical context of the formation of the Germanic languages (30.3\%);

4) comprehending the origins of the Germanic languages and their parent language (33.3\%);

5) studying the bulk of factors, facts and trends reflecting the evolution of the Germanic languages $(18.2 \%)$;

6) learning the linguistic features of the Germanic languages (27.3\%);

7) penetrating the historical roots of modern phenomena in Germanic languages (12.1\%);

8) recognising similarities and differences between the English and German languages as well as their causes $(21.2 \%)$.

The students' comments on the efficiency of Introduction to Germanic Linguistics sporadically feature attempts at assessing the importance of the competences they have acquired in the course, their value for successful professional self-fulfilment in the future or their importance for further educational activities.

\section{Discussion}

Relying on the feedback provided by future teachers of English/German regarding their philological training, in particular in Introduction to Germanic Linguistics as an elective course, proved to be a constructive strategy for solving the problem of our scientific research. The collected data, despite their variability, ambiguity and sometimes even diametrical opposition, give us grounds for understanding its essential aspects and constitutive characteristics (i.e. content, structure, organization, educational significance and efficiency) from a completely new perspective, namely in the light of its direct participants' suggestions. The systemization, analysis and generalization of the information obtained in the study also allow for revealing the specifics of the propaedeutic course of Germanic linguistics in the system of linguistic training of future teachers of English/German as well as understanding the prospects for its improvement.

Therefore, according to the results of the study, Introduction to Germanic Linguistics is characterised by a high relevance of the informational content, logical topic structuring, proper course load balance, constructive organization and conformity of methodological tools, which were all given high ratings. Against the background of the respondents' majorly positive feedback on the high-quality content and teaching materials, a slightly higher frequency of average ratings of the course organization and, most of all, load is clearly visible. These data correlate with the students' requests to improve the organization of Introduction to Germanic Linguistics, the amount of content and the proportions of different types of educational activities. Therefore, the students' suggestions call for a more efficient redistribution of the academic hours for classroom work and independent work, given the considerable amount and complexity of the informational content of the course which is likely to generate problems in the process of self-study due to the thematic 
idiosyncrasies of Germanic linguistics as a discipline. Another suggestion is to enhance the organizational flexibility of the course in accordance with the rapid, radical and unpredictable changes and phenomena in modern education, such as distance learning during the COVID-19 pandemic.

Meanwhile, the students' feedback on the relevance of Introduction to Germanic Linguistics to the structure of professional training of teachers of English and German is much more ambiguous. Against the background of a clear emphasis on the high quality of its professional and scientific information content, a high percentage of average and low ratings is noticeable in the assessment of its connection with the profession realities and compliance with the respective speciality. The respondents see the solution to the problem in additionally highlighting the English and German linguistic phenomena, processes and trends that are studied. The obvious reason for such considerations is, first and foremost, the fundamental orientation of Introduction to Germanic Linguistics towards linguistic theory and language history, which involves approaching the languages in question in their historical and modern interactions. This overly theoretical nature of the discipline, in its turn, accounts for the indirectness of its connection with the professional activities of a teacher of English/German. Thus the course focuses on the context of language development from the past to the present and prioritises the interpretation of the causes of linguistic phenomena or units rather than elaborating on their diversity. These idiosyncrasies of the discipline make it impossible to fully take into account the students' suggestions to shift the focus onto English and German exclusively, since this approach do not illustrate the full range of evolutionary trends of the Germanic language group.

Furthermore, the positive feedback provided by the overwhelming majority of the respondents on the course efficiency conclusively proves that it is an important means of linguistic training aimed at English/ German teacher training. According to the students' assessment of their own academic achievements, the course allows for comprehending a wide range of issues covering the context of formation and the laws of evolution of the Germanic languages from their origins to the present as well as the systematic correspondences existing between them. Its efficiency is regarded to be manifested primarily through focusing on the essential characteristics of the Germanic languages as a separate group in general along with the formation peculiarities of each language viewed from the perspective of its group interconnections and interactions in particular. The optional course was largely seen by the students as a guide to understanding the origin and development of the Germanic languages in a broad context, the hierarchy of their interrelationships and the nature of their interactions, the historical roots of their modern phenomena, etc., which, according to the respondents' feedback, helped to form a holistic view of the Germanic language group as well as to identify the places of English and German in it.

The data obtained in our study largely fit the overall picture of the results of scientific research on similar issues. Thus, Banegas (2020) stated the ambiguity of foreign (namely, English) language teachers' attitude towards mastering Introduction to Linguistics in the process of their professional training. On the one hand, its participants confirmed the positive impact of the discipline on improving their communicative English language competences as well as on expanding their knowledge of professional terminology. On the other hand, the respondents pointed to a certain remoteness of the discipline from the needs and realities of further professional practice. Hatipoğlu (2017) also found multiple contradictions in future English teachers' opinions regarding the mastery of a number of linguistic courses. The respondents mostly praised the efficiency of the latter in familiarising students with linguistic theories and conceptions, forming a multifaceted view of language phenomena, providing a deeper and more comprehensive understanding of language as a complex entity. However, their negative evaluation of the linguistic courses was similarly caused by their insufficient awareness of the connection existing between the acquired competences and their practical application, since abstract linguistic knowledge may seem irrelevant to practice at first glance. Compared to these two studies, the results of Abreu's research (2015) are somewhat different, revealing the dynamics of how future language teachers' evaluation of the course of Applied Linguistics has changed overtime, which was reflected in two time samples - before starting the course and after completing it. The role of the course in foreign language teachers' professional education got positive feedback from the students, which was especially noticeable upon its completion. Furthermore, the course was recognised as having a significant impact on a thorough understanding of English as an object of both learning and teaching. Therefore, the data of our experimental research correlate more with Banegas' (2020) and Hatipoğlu's (2017) findings rather than with the results of the study by Abreu (2015).

Based on generalising the whole range of the students' opinions concerning Introduction to Germanic Linguistics, we consider it relevant to introduce the course as an auxiliary, additional means of the fundamental linguistic training of highly qualified teachers of English/German. The course opens up new horizons in understanding these languages by comparing the facts of their past and present, the convergence and divergence of their systems as well as their place in the linguistic worldview. Therefore, Introduction to 
Germanic Linguistics expands linguistic knowledge and develops philological thinking, which is likely to contribute to students' educational and professional excellency in the future (Bezliudna, 2017; Bosa, 2019; Volotivska, 2017). The distinctive functions and content of Introduction to Germanic Linguistics as a discipline which is part of linguistic training of future teachers of English/German provide somewhat specific conditions for its effective practical implementation, including: 1) the students' mandatory prior acquaintance with its essence and links with other disciplines; 2) explanation of its applied nature; 3 ) ensuring the optional status of the course; 4) its adaptation to the real level of the students' linguistic competence.

All in all, the results of our study allow for outlining a number of suggestions and recommendations for improving the course of Introduction to Germanic Linguistics in the context of its target audience's expectations and needs. Firstly, it seems necessary to eliminate the disparity in the ratio of the share of selfstudy work to that of classroom work from $2 / 3$ to $1 / 3$, respectively. There is an obvious need to balance the course load of these types of educational activities, primarily by increasing the number of tutorials. In our opinion, the best solution to this problem is an even distribution of the hours: 90 academic hours for classroom work (of which 30 academic hours are lectures and 60 academic hours are tutorials) and 90 academic hours for self-study work. Secondly, it seems appropriate to update the content of Introduction to Germanic Linguistics in the context of the existing priorities in the professional development of future teachers of English/German. This recommendation is aimed at a heavier emphasis on the linguistic phenomena and units representing the languages in question along with a clearer delineation of their phonetic, lexical and grammatical features resulting from the millennial history of English and German developing side by side within the same language group. One of the ways to achieve this goal is to develop a set of practical tasks demonstrating and systemising the regular phonetic, lexical and grammatical correspondences between English, German and other Germanic languages, all united by their common origin. Thirdly, the rationale for increasing the flexibility and variability of the organization of teaching Introduction to Germanic Linguistics is indisputable, especially in the light of the unpredictable challenges and realities of modern life and education. Using the latest information and communication technologies and resources (such as Moodle or Google Classroom learning management systems) that allow a free choice of the student's style, pace and form of learning (Bezliudna, 2017; Dolyna, 2019) is what we consider the most efficient remedy for increasing the organizational flexibility of the educative process in the discipline.

\section{Limitations}

Our study is marked by certain limitations, namely: 1) a small number of the survey participants, which does not reflect the total number of pedagogical university students majoring in English or German, and hence of their evaluative judgements concerning Introduction to Germanic Linguistics; 2) the undergraduate status of the research respondents, which might have had an impact on their answers to certain questionnaire items; 3) a lack of academic studies on the topic, which makes it impossible for us to compare our results with other scholars' findings.

\section{Conclusions}

The present research gives grounds for recognising Introduction to Germanic Linguistics as an effective tool for ensuring the high-quality philological training of teachers of English/German. The course provides a profound understanding of the key issues in Germanic linguistics and offers a comprehensive vision and a broad contextual presentation of these languages in their interrelationships and mutual influences. The results of our experimental research, based on the feedback from the DIFSPU students majoring in English/German, confirm the following statements: 1) the course relevance to language teacher training; 2) the high quality of its content and methodological premises; 3) its efficiency in forming professional competence. The data obtained serve as the basis for enhancing the fundamental linguistic training of teachers of English/German and determining the conditions of its effective practical implementation, which include: 1) the students' prior acquaintance with the essence and specifics of the course; 2) explanation of its applied significance; 3) ensuring the optional status of the course; 4) its compliance with the level of the students' philological knowledge and skills. These conditions, in their turn, outline the possibilities of improvements to be made to the course in the future, such as: 1) balancing the ratio of all types of educational activities; 2) updating the course topics in the context of the existing priorities in the professional development of future teachers of English/German; 3) increasing the flexibility and variability of the course organization. Further work needs to be performed in order to further investigate a range of both variable and invariable components of language teacher training in order to develop a holistic conception of its continuous improvement in 
accordance with the students' individual educational needs, dynamic scientific and linguistic progress as well as the volatile realities of the modern professional world.

\section{References}

Abreu, L. (2015). Changes in beliefs about language learning and teaching by foreign language teachers in an applied linguistics course. In P. Swanson (Ed.), Dimension 2015 (pp. 136-163). Decatur, GA: SCOLT.

Andrews, S. \& McNeill, A. (2005). Knowledge about language and the "Good Language Teacher". In N. Bartels (Ed.), Applied Linguistics and Language Teacher Education (pp. 159-178). Boston: Springer.

Arias-Cepeda, C., \& Rojas, S. (2017). Rethinking Curriculum in the Linguistics Component of a Major on Bilingual Education. Gist: Education and Learning Research Journal, 14, 135-157. https://doi.org/10.26817/16925777.361

Banegas, D. L. (2020). Teaching linguistics to low-level English language users in a teacher education programme: an action research study. The Language Learning Journal, 48 (2), 148-161. https://doi.org/10.1080/09571736.2017.1370604

Başyurt Tüzel, A. E., \& Akcan, S. (2009). Raising the language awareness of pre-service English teachers in an EFL context. European Journal of Teacher Education, 32 (3), 271-287. https://doi.org/10.1080/02619760802572659

Bezliudna, V. V. (2017). Profesiina pidhotovka maibutnikh uchyteliv inozemnykh mov u vyshchykh pedahohichnykh navchalnykh zakladakh Ukrainy (1948-2016 rr.): teoriia i praktyka [Professional training of future teachers of foreign languages in higher pedagogical educational institutions of Ukraine (1948-2016): theory and practice]. Uman, Ukraine: "Sochinskyi M. M."

Bigelow, M., \& Ranney, S. (2010). Knowledge about Language for Teachers is More than Knowing Grammar Rules. Studies in Hispanic and Lusophone Linguistics, 3(1), 217-228. https://doi.org/10.1515/shll-2010-1070

Bosa, V.P. (2019). Formuvannia movlennievoi kompetentnosti maibutnikh uchyteliv inozemnykh mov u protsesi vyvchennia fakhovykh dystsyplin [Formation of linguistic competence of future foreign language teachers in the process of professional disciplines' studying]. Zhytomyr, Vyd-vo ZhDU im. I. Franka.

Correa, M. (2014). Teaching (theoretical) linguistics in the second language classroom: Beyond language improvement. Porta Linguarum, 22, 161-171. https://doi.org/10.30827/Digibug.53738

Dolyna, A. V. (2019). Vykorystannia systemy Moodle dlia vdoskonalennia fonetychnoi kompetentnosti maibutnikh uchyteliv anhliiskoi movy [Improving pre-service foreign language teachers' phonological competency with Moodle]. Information technologies and learning tools, 70 (2), 205-215. https://doi.org/10.33407/itlt.v70i2.2382

Kemin, V.P., Slipetska, V.D., \& Markova, M.V. (Eds.) (2019a). DIFSPU Bachelor's Programme in the specialty 014 Secondary education (Language and Literature (English)) in the field of knowledge 01 Education / Pedagogy. Retrieved 5 December 2020 from http://dspu.edu.ua/wp-content/uploads/2020/03/an-b-1.pdf

Kemin, V.P., Slipetska, V.D., \& Markova, M.V. (Eds.) (2019b). DIFSPU Bachelor's Programme in the specialty 014 Secondary education (Language and Literature (German)) in the field of knowledge 01 Education / Pedagogy. Retrieved 5 December 2020 from http://dspu.edu.ua/wp-content/uploads/2020/03/na-b.pdf

Ellis, E. (2012). Language awareness and its relevance to TESOL. University of Sydney Papers in TESOL 7, 1-23. Retrieved 10 December 2020 from https://faculty.edfac.usyd.edu.au/projects/usp_in_tesol/pdf/volume07/Article01.pdf

Fenwick, L., Humphrey, S., Quinn, M., \& Endicott, M. (2014). Developing Deep Understanding about Language in Undergraduate Pre-service Teacher Programs through the Application of Knowledge. Australian Journal of Teacher Education, 39(1). http://dx.doi.org/10.14221/ajte.2014v39n1.4

Hatipoğlu, Ç. (2017). Linguistics courses in pre-service foreign language teacher training programs and knowledge about language. ELT Research Journal, 6 (1), 45-68. Retrieved 12 December 2020 from https://dergipark.org.tr/tr/pub/eltrj/issue/28779/307997

Lipinska, I. O. (2013). Zmist profesiinoi ta praktychnoi pidhotovky vchyteliv-filolohiv shyrokoho profiliu $v$ Ukraini: istoriia $i$ suchasnist [The content of professional and practical training of teachers of philology of a wide profile in Ukraine: history and modernity]. Pedahohichna osvita: teoriia i praktyka, 14, 196-201. Retrieved 13 December 2020 from http://nbuv.gov.ua/UJRN/znppo_2013_14_39

Melnychenko, H. V. (2016). Interaktyvni pryiomy rozvytku profesiinoi kompetentnosti maibutnoho vykladacha inozemnykh mov zasobamy navchalnoho kursu "Istoriia anhliiskoi movy" [Interactive methods of developing the professional competence of a future foreign language teacher through the course "History of English"]. Naukovi zapysky Natsionalnoho universytetu "Ostrozka akademiia". Seriia: Filolohichna, 61, 189-191. Retrieved 13 December 2020 from http://nbuv.gov.ua/UJRN/Nznuoaf_2016_61_74

Mendelsohn, D. (2011). The value of linguistics to the ESL/EFL classroom practitioner. In K. Kuiper (ed.), Teaching linguistics: Reflections on practice (pp. 145-153). London: Equinox.

Otwinowska, A. (2017). English teachers' language awareness: away with the monolingual bias? Language Awareness, 26, $304-324$. https://doi.org/10.1080/09658416.2017.1409752

Volotivska, I. I. (2017). Fakhova pidhotovka vchytelia inozemnoi movy v period stanovlennia nezalezhnosti Ukrainy [Professional training of a foreign language teacher during the period of establishment of independency of Ukraine]. Pedahohichni nauky, 78 (1), 15-18. Retrieved 14 December 2020 from http://nbuv.gov.ua/UJRN/znppn_2017_78\%281\%29_4 